\title{
The Representation of Motherless and Fatherless Homes in Novels of George Eliot
}

\author{
Tahira Jabeen ${ }^{1}$ \\ ${ }^{1}$ Department of English, The University of Azad Jammu \& Kashmir, Muzaffarabad \\ Correspondence: Tahira Jabeen, Department of English, The University of Azad Jammu \& Kashmir, \\ Muzaffarabad, Azad Kashmir, Pakistan. E-mail: wee4t@yahoocom
}

Received: August 23, 2019 Accepted: September 15, 2019 Online Published: November 14, 2019

doi:10.5539/ells.v9n4p33 URL: https://doi.org/10.5539/ells.v9n4p33

\begin{abstract}
George Eliot wrote about the social, cultural, and historical issues of her time. She represented the middle-class homes in her novels and showed how the Industrial Revolution changed the very setting of domestic environment. The home became the domain of women, where they were to fulfil the nurturing duties while men moved to work place to provide for their dependents. In middle class families, the nurturing duty was not the domain of the father only in the society of this period. Fathers and mothers substituted their duties either under extraordinary circumstances or as a matter of choice. This study analyses the substitution of duties by fathers and mothers in Eliot's novels with the help of comprehensive and interdisciplinary supporting literary, social, and historical resources like magezines and books, from the Victorian age. The study concludes that George Eliot's homes are not perfect without a benevolent mother and responsible father.
\end{abstract}

Keywords: George Eliot, nineteenth century, fathers, mothers

\section{Introduction}

After the Industrial Revolution, men moved to the work places in an industrial setting, and home became the domain of women where they were responsible for nurturing and providing. With these rapid cultural and social changes in the nineteenth century Britain, the change in the role of the father was dramatically peculiar since motherhood during this time was also undergoing tremendous changes and "the cult of motherhood began to monopolize parenting" (McKnight, 2011, p. 1). One of the facts that demonstrate this shift is the publication of "conduct books". Written in the seventeenth and eighteenth centuries, these books advised fathers on how to guide the lives of their sons. These conduct books were written by well-known writers, the best examples being Letters to His Son by Lord Chesterfield and Addresses to Young Men by James Fordyce. They aimed to produce a man who was "virtuous, gentle, and possessed of sincerity, compassion, generosity, bravery, disinterest and magnanimity" (Wright, 1962, p. ix). Furthermore, The Gentlemen's Magazine from 1778 to 1815 emphasized "connectedness" or the ability to sustain relationships with family and friends (Stafford, 2008, p. 53).

Beginning in the nineteenth century, conduct books written by and for women became more common. Natalie McKnight (2011, p. 52) mentions that "conduct books began focusing on women as the chief domestic agent." According to McKnight, if we look up the words "father" and "fathering" in Poole's Index of the nineteenth century periodicals, there are only seven seemingly relevant entries as compared to twenty-three for "mothers" or "mothering" for the same time span. Likewise, Broughton and Rogers (2007, pp. 6-7) refer to the same phenomenon, writing that "where hitherto advice on the running of the house had been aimed principally at men, women now became the target audience of household literature and guides to parenting." A few of the popular conduct books for women were Women of England, Wives of England, and Mothers of England by Sarah Ellis, Women's Mission by Sarah Lewes, and Household Management by Isabella Beeton. These books helped to establish the "cult of motherhood", which placed mothers in the home and fathers outside the home as the struggling breadwinner and titular head of the family (McKnight, 2011, p. 2).

The eighteenth-century male's involvement in family life is studied by Lisa Forman Cody (2005, p. 304), whose central focus is the triumph of male midwives over the traditional female practitioners of midwifery, a familiar theme to British historians of eighteenth-century gender studies and medicine. For her, this new practice "suggested new models of masculinity and fatherhood." There is consensus among historians that until the rise of this domestic ideology at the end of the eighteenth century, fathers were actively involved in the nurturing and 
training of their children, and that they were leading family celebrations and rituals. Cody mentions the rise of the new ideals and changes due to the Industrial Revolution and the new religious practices, which polarized sexual differences, producing rigid, separate spheres of life for both genders.

"It was regarded as natural for women to take up the whole duty of motherhood," and "it was expected that all women, whether biological mothers or not, had a maternal instinct" (Davidoff \& Hall, 2002, p. 335). Women were cut off from any direct contribution to enterprises. They were defined by their relation to men for whom the private sphere or home was a relaxation from the labour, hard work and anxiety of economic activities. This distinction was made mainly in middle class households, where men were the providers and the protectors of the family. Eliot represented middle class in her novels. The family life is a prominent subject of her stories. Although George Eliot has been regarded as a historical source of her time in terms of her realistic novels, how the historical events brought about a change in the patriarchal structure of the family is largely ignored. She represented a variety of fathers and mothers in different situations. Some of her stories show the substituting of duties by fathers and mothers. In the following lines, this representation of substitution of duties is analysed with the help of comprehensive and interdisciplinary supporting literary, social, and historical resources from the Victorian age.

\section{Nurturing Silas Marner and Amos Barton}

This section will examine the mothering fathers in the novels of George Eliot, and explore the circumstances in which a father has to take on the nurturing responsibility and how the father copes with this unusual obligation for a nineteenth century male. In the case of the titular character of Silas Marner, he finds a parentless child, and in the case of Amos Barton in Scenes of Clerical Life, the mother dies, leaving the father with five children. In these extreme circumstances, the father has to nurture the children and maintain the household.

Usually, fathers are not interested in nurturing children. Amos Barton does not show any interest in nursery when his wife is alive, and when he comes home from work, finding his wife busy with the youngest child, he just asks her, "So the young rascal won't go to sleep! Can't you give him to Nanny?" (Eliot 1857, p. 20) When the mother is there, he has no concerns. But after the death of Mrs. Baton, he is left alone to care for the children, support and provide for them. Tosh $(1999$, p. 88) elaboates that "in bourgeois culture at this time ... the rearing of infants now tended to be secluded from the rest of the household in a nursery, preferably staffed by specialist servants. The nursery was not a place where men felt at their ease."

Furthermore, the story of Amos Barton shows the nurturing and upbringing of children. In middle class homes, nannies were usually responsible for the hygiene of both nursery and child, and mothers just supervised their households, while fathers were even less involved with these activities. Even at the time of the birth of a child, men were mostly concerned with their specific responsibility of providing for them. As providers, they felt the need to be economically strong in order to provide a better environment. John Tosh (1999) explains:

Often what was uppermost in the mind of the expectant father was the added burden of material provision. Middle-class fathers were seldom on the bread line, but they certainly faced job insecurity, and failure in business was all the more traumatic if there were the needs of children to be taken into account. Childbirth was therefore a moment when awareness of a father's material responsibility was particularly intense. But that sense was integral to the whole experience of fatherhood. Full acceptance as a man in society depended on manifestly possessing the independence and the resources to be a household head (p. 82).

When Amos Barton returns following the burial of his dear wife, with five children around him in his hollowed house, the narrator describes his feelings: "Amos, for the first time, felt that he is alone - that day after day, months after months, years after year, would have to be lived through without Milly's love" (Eliot, 1857, p. 47). Amos Barton faces a double-edged challenge - not only does he need to fulfil the role as a nurturing mother, he also needs to secure his job in order to fulfil his financial responsibilities for his dependents. His annual stipend of eighty pounds as a clergy man is already not enough to provide for his family, and his wife had been helping him to meet the expenses of the home with her knitting. The narrator provides no detail about how he copes with this dual responsibility of providing and nurturing, but she describes that after twenty years, when he comes to Milly's grave with his children all grown up, he is proud that he has the ability to fulfil the role as a nurturer for his children.

The case of Silas Marner is very extraordinary. Silas, a single man who has been living in the village of Raveleo for fifteen years, doesn't have any social connections. He is a man isolated from the rest of the community, and the gold he has been accumulating is the only pleasure that he has in life. But when his gold is robbed, he is left bewildered and melancholic. When he finds a child on his door step, the child seems to Silas to come as an alternative to the gold: "it seemed as if there was gold on the floor. Gold!- -his own gold...but his fingers 
encountered soft warm curls" (Eliot, 1861, p. 135). He names the child Eppie and adopts her as his own, and in the next moment Silas is no longer desolate with loss. Eppie becomes the object of Silas' attention. He makes porridge for her and washes her muddy shoes. The child becomes the only thing from which he is not ready to be separated. He repeatedly expresses this change: "The money is gone, I don't know where, and this came from I don't know where" (Eliot, 1861, p. 148). He is not willing to let others do anything for the child. When Dolly, his neighbour, offers help to put clothes on the child, he says, "I want to do things for it myself."

Silas couldn't give Eppie a wealthy life, yet Eppie is happy to stay with him in his small cottage. And when for the first time the child cries with "mammy", "he unconsciously utters sounds of hushing tenderness" (Eliot, 1861, p. 39). Eliot describes the effect on Silas, revealing that while the "child's life was unfolded, his soul was unfolding too" (Eliot, 1861, p. 37). She changes Silas' world so that his love and pleasure in life is rejuvenated. For the first time since coming to Raveleo, Silas becomes part of the community.

Eppie's biological father, Godfrey Cass, cares for her and wants to make sure that she is provided for. He goes to Silas Marner and wants to help him, saying "let me give something towards finding it clothes" (Eliot, 1861, p. 144). Godfrey cannot bear to end performing fatherly duties in the form of provider. "He told himself that time would come when he might do something towards furthering the welfare of his daughter ... that he would see that it was well provided for. That was a father's duty" (Eliot, 1861, p. 161). The contrast between nurturing fathers and biological fathers is shown well in the scene where Godfrey comes to see the child. Although he cannot keep himself away from the fatherly feelings and offers money to buy garments for the child, he is not willing to tell or show the true feelings he has for his own child and is unable to claim the child as his own.

Thus, the efforts of the provider are juxtaposed in Silas Marner. It is the fathering responsibilities that attaches Silas Marner to the world around him, reviving what he has abandoned before, such as family, companionship, neighbouring and, most importantly, faith in God. This juxtaposition of fathers was the result of George Eliot's own biographical experiences. In her novels, some of the natural fathers are not acceptable to their own children. Eliot's disbelief in the natural father is illustrated in Eppie's rejection of Godfrey's offer to go with him. Silas, the nurturing father, has won Eppie's love. "Silas, the surrogate father, is chosen over the natural father with wealth and status" (Ayaka, 2006, p. 22). On the other hand, Silas cannot bear to part from the child, saying "I can't let it go, it came to me-I have right to keep it" (Eliot, 1861, p. 140).

According to Komiya Ayaka, in Eliot's novels, thnurturing fathers are always successful. But if we look at these nurturing fathers, we find that they take the nursing role only under certain circumstances: in Amos Barton's case, the death of his wife, and in Silas Marner's case, the parentless child makes him take on the role of nurturer. Secondly, in The Mill on the Floss, the father tries to fulfil his responsibilities as the provider even though he cannot cope with the existing economic situation. So, Eliot also showed the biological fathers engaged in their fatherly duties. They could be regarded as a failed miller or a failed clergy man (Mr. Tulliver and Amos Barton respectively), but as fathers, their efforts for their children are worthwhile.

Moreover, these nurturing fathers are not alone in taking on this job of raising a child, and because it's not among their natural domestic duties, they always need the help of a woman to provide a mother figure for the children. In the case of Amos Barton, he is helped by his eldest daughter in caring for the children, as advised by her mother on the death bed. And even though Silas Marner does not want to have things done for the child by anyone else, he still needs a mother figure in order to care for little Eppie, a role filled by Dolly, a neighbouring lady who performs this duty, teaching Silas "womanly tender acts" that make the child forget about her own mother.

In the nineteenth century, the ideal middle-class family was organized around the ideology of "separate spheres" where the father, with masculine power, was considered aggressive and active, which enabled him to negotiate in the public world of business and work. But child caring requires a nurturing temperament, passivity, femininity; for men to exhibit these characteristics in the sphere of work could debase his masculinity. At the same time, such characteristic in the home was resisted by society in general. Tosh $(1999$, p. 87) explains that "as the gendered character of man and woman, of father and mother, became more polarized, there was less tolerance for paternal behaviour which appeared to encroach on the maternal role." So, nurturing by men was considered a subversion of the masculine ideal.

These were the values of the middle-class families, but the working-class families were different. Terri Sabatos (2007) in her essay "The Image of the Widower with Children in Victorian Art" analyzes the cases of three widowed fathers with their children. She asserts that the middle class always felt anxiety about the working class, because the working class was more willing to accept the subversion of the hegemonic masculine ideal. She argues that the "humble" fathers of the working class shared the values of the middle class: "even when it was 
thrown into the death of the wife and mother, gender boundaries might remain intact and the respectable working-class father might assume his patriarchal duties by taking care of his family" (in Broughton \& Rogers, 2007, p. 82).

Silas Marner's and Amos Barton's journeys from social isolation to social integration come through their losses and discoveries. Amos Barton loses his wife, and then comes to know his responsibilities and receives the sympathies of the people of Shepperton. And while Silas faces many upheavals in his life-shunning his faith and society, deception and loss of his gold - his faith in God and people, his happiness in life, is restored by the girl. So, Eliot created situations in her novels where the fathers who care for daughters in a domestic setting gain in life. Silas and Amos both gain public sympathy, and caring for the children becomes, for them, a harbinger of happiness.

\section{The Role of Mothers in Fatherless Homes}

In the last section, the representation of mothering father is elaborated. Now an important question is, whether and how does Eliot empower mothers to take on the responsibilities of guiding and protecting the children to fill the gap created by the aloofness or absence of the fathers. Or, we may ask, how is vacancy of fatherhood filled in the household? Or how is inadequacy of fatherhood, if there is, overcome? In the nineteenth century "expectations for mothers differed from the father's role in significant ways. Mothers were to be relied upon for personal care and emotional rather than economic support" (Davidoff \& Hall, 2002, p. 335).

Eliot had an acute understanding of the separate sphere ideology of her time. However, Eliot would not "admit woman's full equality with man because she felt that the complete emancipation of her sex might coarsen the feminine nature" (Petrie, 1973, p. 8). She showed her female characters struggling against oppression as well as coping with their duties in and outside of home. Here the analysis of some of the mother characters in Eliot's novels is presented to demonstrate how mothers carried out their duties outside their private sphere or domesticity.

In Felix Holt and Adam Bede, Eliot portrays strong mothers who try to make the decisions for themselves and their families, instead of the fathers, whose presence is barren in both novels. Mrs. Transome in Felix Holt dominates her husband. Because of Mr. Transome's senility, she manages the Transome estate during her son's absence. The father's "diminished masculinity and authority" (Cole, 2011, p. 172) restricts him to the library where he plays with his grandson, Harry. His activities are described by the narrator: "There was Old Mr. Transome with a cord around his waist, playing a very poor-paced horse for a black-maned little boy about three years old, who was urging him on with loud encouraging noises and occasional thumps from a stick" (Eliot, 1866, p. 128).

The image of a "poor-paced horse" shows the submission and weakness of Mr. Transome (Cole, 2011, p. 172). Mr. Transome, in other words, has no ability to manage his home and the emperor of the household loses his masculine pride and cannot fulfil the norms of masculinity, which are set by the society of the time, because at the time, "to establish a home, to protect it, to provide for it, to control it, and to train its young aspirants to manhood, have usually been essential to a man's good standing with his peers. Masculinity, after all, was essentially about being master of one's own house... indeed rule as 'father' embodied the primary meaning of term "patriarchy"' (Tosh, 1999, p. 8).

It seems to me that Mr. Transome's loss of mastery of his home gives a passageway to others to achieve mastery in the home and thus the home loses its moral centre.

Mr. Transome is "being like a distracted insect", to use his wife's remark, and his "crawling among books", in Harold's words, like "a timid animal in a cage", showing the father's escapism from the outer life, which he cannot face. It is for this weakness that the mother assumes the father's economic role and continues to use her authority to shape her son's political career. Harold also decides to fulfil the father's role of authority, which his father has lost long ago. Mr. Transome has no more role in his son's political life, and the mother is too egoistical for the son to follow her. Harold often discusses the political matters with his mother and, because of her egoistic nature; she wants her son to act according to her advice. The narrator points out that Harold leaves her when he is a boy; she indulges herself in the dream that he would come back a boy (Eliot, 1866, p. 108). She tries to keep her hold on the private sphere as well as on the public sphere by dictating her son's life. But she is shocked when he takes the reins of the estate in his hands and announces his decision to run for parliament election as a Radical candidate, breaking away from family tradition regarding politics.

Mrs. Transome regards her son to be "masterful beyond anything". The narrator describes Harold as "fond of mastery and good-natured enough to wish that everyone about him should like his mastery" (Eliot, 1866, p. 111, 
136). The use of the word "master" for Mrs. Transome shows their hold in the home and their obstinate nature. Zimmerman (1979, p. 434) calls it a political image, and sees it as a "derogatory synonym" of power which "assumes an egoistic form". Mrs. Transome manipulates the sexual as well as maternal powers. Zimmerman points out that "as a young woman she had tyrannized her husband through her strong will and her lover through sexual fascination; as an old woman she attempts to satisfy her frustrated desires through Harold's political career". I agree with Zimmerman that the use of power actually upsets the social order which existed for women during the nineteenth century. Their power to do mischief is the power to "hinder men's lives from having any nobleness in them" (Eliot, 1866, p. 209). Due to her manipulating character, Harold rejects her suggestion for marrying an English woman, he says, "Would you have had me wait for a consumptive lackadaisical Englishwoman, who would have hung all her relations round my neck? I hate English wives; they want to give their opinion about everything. They interfere with a man's life. I shall not marry again" (Eliot, 1866, p. 210). His viewpoint is distorted, and he, not only rebels against her, but also rejects English women in general. Harold believes in warmth and comfort which he couldn't receive from his mother. And she also, as a mother, is not able to understand her son's inclinations.

When it is disclosed that Harold is the illegitimate son of Mr. Jermyn, the lawyer of family estate, Harold is deprived of the Transome estate. In this situation Mrs. Transome, takes over the father's role, deviates from her private sphere as a wife and mother. But some of her moves bring trouble not only for herself but for the whole Transome family. By going beyond her authority, Mrs. Transome spoils the honour and fortune of her family. In the epigraph to chapter 42 of Felix Holt, Eliot quotes from Sophocles' Electra: "Thou sayst it, and not I; for thou hast done/The ugly deed that made these ugly words" (Eliot, 1866, p. 331). Rita Bode comments that "the quotation not only affirms the close ties between language and action, but also emphasizes the great import that action itself holds. Some deeds result in irreversible consequences which continue to haunt the person who commits them (Bode, 1995, p. 779).

Mrs. Transome "was a master, had come of a high family, and had a spirit", warns Jermyn in his conflict with Harold, but her past relationship with Jermyn provides the lawyer with a loophole for exploitation: "No, it is not the extent of your power. You could save me if you would. It is not to be supposed that Harold would go against me ... if he knew the whole truth" (Eliot, 1866, p. 336). She is trapped in a situation which is a consequence of her adulterous crime.

Leonore Davidoff and Catherine Hall (2002, p. 115) emphasize that in the nineteenth century, from their protected place of home - their private sphere-women "could wield their moral influence and thus save not only themselves but men as well." Similarly, Poovey (1984, p. 10) argues that "as superintendents of the domestic sphere, (middle-class) women were represented as protecting and, increasingly, incarnating virtue." But Mrs. Transome could not make her home a haven and brings trouble for her son and for the whole Transome family because she deviates from the norms of the nineteenth century by exploiting her power and dismissing the authority of her husband.

Adam Bede's mother, Lisbeth, has such influence and I agree with Mary Ellen Doyle (1981, p. 25), who argues that Lisbeth "is a touchstone by which Adam's progress in sympathy is tested." I think she also has an impact on Adam's moral growth and thus serves as a guide and protector for her sons, which the father couldn't continue. At the same time, Lisbeth is "at once patient and complaining, self-renouncing and exacting, brooding the livelong day over what happened yesterday, and what is likely to happen tomorrow, and crying very readily both at the good and the evil" (Eliot, 1861, p. 102).

Sopher regards Lisbeth as a hysteric mother and asserts that Eliot, "by emphasizing Lisbeth's emotionality and its excessiveness, paints it as exceptional, rather than as the expected expression of normative femininity and maternity," which challenges the "stereotypes about femininity and emotion" (Sopher, 2012, p. 7189). At this point I disagree with Sopher. I think that because of her emotional perception Lisbeth is the first person to recognize that Dinah has fallen in love with Adam. She wants them to marry, saying that Dinah will "ne'er go away, I know, if Adam 'ud be fond on her an' marry her" (Eliot, 1859, p. 532). While Mrs. Transome in Felix Holt wants her son to consult her in everything, Lisbeth Bede in Adam Bede, though a vigorous old woman, is aware of her sons' feelings and helps them to achieve their goals. Lisbeth Bede also takes care of her husband and worries about his alcoholism.

Thus, George Eliot's homes are not perfect without a benevolent mother and responsible father. Lisbeth Bede in Adam Bede proves herself an impeccable mother, but the home still needs the father's involvement. The decrepit father and authoritative mother in Felix Holt make the household scene even worse. And without a mother or mother figure, the father in Silas Marner neglects his role as guide and protector, leaving the home with no 
centrality.

\section{References}

Ayaka, K. (2006). George Eliot's Fantasy on Parenthood. Liberal Studies, 21-35. Meiji University.

Bode, R. (1995). Power and Submission in Felix Holt, The Radical. Studies in English Literature, 1500-1900, 35(4), 769-788. https://doi.org/10.2307/450765

Broughton, T. L., \& Helen, R. (Eds.). (2007). Gender and Fatherhood in the Nineteenth Century. Palgrave Macmillan. https://doi.org/10.1007/978-0-230-20785-1

Cody, F. L. (2005). Birthing the Nation: Sex, Science, and the Conception of Eighteenth-Century Britons. Oxford University Press.

Cole, N. B. (2011). 'The Right 'O Things by my Own Fireside': Masculinity and Fatherhood in George Eliot's Fiction. In M. Natalie (Ed.), Fathers in Victorian Fiction (pp. 153-184). Cambridge Scholars Publishing.

Davidoff, L., \& Hall, C. (1987). Family fortunes: Men and women of the English middle class 1780-1850. London: Hutchinson.

Doyle, M. E. (1981). The Sympathetic Response: George Eliot's Fictional Rhetoric. London: Associated University Presses.

Eliot, G. (1859). Adam Bede. Oxford World's Classics. Oxford: Oxford University Press.

Eliot, G. (1861). Silas Marnar. Oxford World's Classics. Oxford: Oxford University Press.

Eliot, G. (1866). Felix Holt, The Radical. London: The Hawarden Press.

Petrie, A. G. (1973). Treatment of women in the novels of George Eliot. University of British Columbia. Retrieved from https://open.library.ubc.ca/collections/ubctheses/831/items/1.0101492

Poovey, M. (1984). The Proper Lady and the Woman Writer: Ideology as Style in the Works of Mary Wollstonecraft, Mary Shelley, and Jane Austen. Chicago and London: University of Chicago Press.

Sopher, R. E. (2012). Peripheral Sympathies: Gender, Ethics, and Marginal Characters in the Novels of George Eliot. Open Access Dissertations and Theses.

Stafford, W. (2008). Gentlemanly Masculinities as Represented by the Late Georgian Gentleman's Magazine. History, 93, 47-68. https://doi.org/10.1111/j.1468-229X.2008.00413.x

Tosh, J. (1999). A Man's Place: Masculinity and Middleclass Home in Victorian England. Yale University Press.

Wright, L. B. (Ed.). (1962). Advice to a Son-Precepts of Lord Burghley, Sir Walter Raleigh, and Francis Osborne. Ithaca, New York.

Zimmerman, B. (1979). Felix Holt and the True Power of Womanhood. ELH, 46(3), 432-451. https://doi.org/10.2307/2872689

\section{Copyrights}

Copyright for this article is retained by the author, with first publication rights granted to the journal.

This is an open-access article distributed under the terms and conditions of the Creative Commons Attribution license (http://creativecommons.org/licenses/by/4.0/). 